\title{
Functional capacity assessment of long-lived older adults from Amazonas
}

\author{
Avaliação da capacidade funcional de idosos longevos amazônidas \\ Evaluación de la capacidad funcional de ancianos longevos amazónicos
}

Daiane de Souza Fernandes ${ }^{1,11}$
ORCID: 0000-0001-6629-4222

Lucia Hisako Takase Gonçalves' ORCID: 0000-0001-5172-7814

Angela Maria Rodrigues Ferreira' ORCID: 0000-0001-6321-7512

Maria Izabel Penha de Oliveira Santos' ORCID: 0000-0002-7840-086X

'Universidade do Estado do Pará, Belém, Pará, Brazil. "Universidade Federal do Pará. Belém, Pará, Brazil.

How to cite this article: Fernandes DS, Gonçalves LHT, Ferreira AMR, Santos MIPO. Functional capacity assessment of long-lived older adults from Amazonas. Rev Bras Enferm. 2019;72(Suppl 2):49-55. doi: http://dx.doi.org/10.1590/0034-7167-2017-0798

Corresponding Author:

Daiane de Souza Fernandes E-mail: daissf@yahoo.com.br

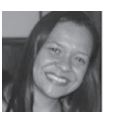

Submission: 09-01-2017 Approval: 06-16-2018

\begin{abstract}
Objective: To evaluate the functional capacity of long-lived older adults from Amazonas. Method: A cross-sectional epidemiological study was carried out with 116 older adults aged 80 years or older, registered in a primary health care unit in Belém, in the state of Pará, Brazil. The Functional Independence Measure (FIM) was used for functional capacity assessment and the Mini-Mental State Examination (MMSE) for cognitive screening. Univariate and bivariate analyses were carried out, in addition to the Pearson's chisquare test. Results: The older adults presented modified independence in the self-care, sphincter control and locomotion dimensions, and needed supervision for mobility/ transfers. In mobility, men presented complete independence. Modified independence was found in the 80-89 age group. It was observed that, the lower the education level, the worse the cognitive performance. Conclusion: In spite of their advanced age, long-lived older adults still present functional capacity for activities of daily living, even though they required supervision for high energy expenditure tasks, such as mobility and transfers. Descriptors: Aged, 80 and Over; Activities of Daily Living; Public Health; Health of the Elderly; Nursing.
\end{abstract}

\section{RESUMO}

Objetivo: Avaliar a capacidade funcional de idosos longevos amazônidas. Método: Estudo epidemiológico, transversal, realizado com 116 idosos com idade igual ou superior a 80 anos, cadastrados em uma Unidade Municipal de Saúde em Belém-Pará, Brasil. Para avaliação da capacidade funcional, utilizou-se a Medida de Independência Funcional (MIF) e, para rastreio cognitivo, o Mini-Exame do Estado Mental. Realizou-se a análise univariada e bivariada, além do teste Qui-Quadrado de Pearson. Resultados: Os idosos apresentaram independência modificada nos domínios autocuidado, controle de esfíncteres, locomoção e supervisão na mobilidade/transferência. Na mobilidade, os homens apresentaram independência total. Na faixa etária de 80 a 89 anos, observouse independência modificada. Notou-se que quanto menor a escolaridade, pior o desempenho cognitivo. Conclusão: Apesar da idade avançada, os longevos ainda apresentaram capacidade funcional para o cotidiano, mesmo que necessitassem de supervisão para as tarefas de maior gasto energético como a mobilidade e transferência. Descritores: Idoso de 80 Anos ou Mais; Atividades Cotidianas; Saúde Pública; Saúde do Idoso; Enfermagem.

\section{RESUMEN}

Objetivo: Evaluar la capacidad funcional de ancianos longevos amazónicos. Método: Estudio epidemiológico, transversal, realizado con 116 ancianos de edad igual o mayor a 80 años, registrados en una Unidad Municipal de Salud de Belém-Pará, Brasil. Para evaluar la capacidad funcional se utilizó la Medida de Independencia Funcional (MIF), y para la evaluación cognitiva, el Miniexamen del Estado Mental. Se aplicó análisis univariado y bivariado, además del test de Chi-cuadrado de Pearson. Resultados: Los ancianos mostraron independencia modificada en los dominios autocuidado, control de esfínteres, locomoción y supervisión de la movilidad/transferencia. En la movilidad, los hombres demostraron independencia total. En la faja etaria de 80-89 años se observó independencia modificada. Se notó que los menos escolarizados tenían peor desempeño cognitivo. Conclusión: A pesar de su edad, los longevos presentan aún capacidad funcional para su día a día, precisando supervisión para las tareas de mayor gasto energético, como movilidad y transferencia.

Descriptores: Anciano de 80 o Más Años; Actividades Cotidianas; Salud Pública; Salud del Anciano; Enfermería. 


\section{INTRODUCTION}

Older adults aged 80 years or older represent an increasing age group within the population ${ }^{(1-2)}$. In this profile, it is estimated that, in 2050, long-lived older adults will be responsible for one-fifth of the elderly in the world ${ }^{(3-4)}$. In Brazil, this group represented $1.7 \%$ of the population in 2011, which corresponds to more than 3 million older adults ${ }^{(5)}$.

One of the concerns is that the increase in longevity will be followed by higher levels of disease, which means disability and dependence, thus increasing demands for healthcare services and welfare ${ }^{(1)}$. Because the aging process occurs in a heterogeneous way, individuals from the same age group may present different functional capacity from each other ${ }^{(6-7)}$. Functional capacity has been mostly understood in terms of physical and mental abilities, as well as independence to perform specific basic and instrumental activities of daily living $^{(8)}$. In addition, this term is characterized by the presence of individual capacity for decision and command on actions, establishing and following its own rules, as well as capacity for undertaking something with its own means.

Studies emphasize the need for functional capacity assessment of older adults, because it may indicate future healthrelated complications, such as physical disability, frailty, institutionalization, and early mortality ${ }^{(9-12)}$.

The increase in the number of older adults worldwide arouses concerns for governments, because this situation may lead to a greater demand for healthcare systems due to the increase in longevity and emergence of chronic non-communicable diseases, which represent a major challenge ${ }^{(9,13)}$. Long-lived older adults, due to the aging process, tend to present more comorbidities $^{(14-15)}$.

It is worth mentioning that long-lived older adults have been poorly represented in aging-related studies ${ }^{(1-2,4,16-17)}$, and data on this theme are often based on relatively small samples ${ }^{(1)}$. There is a gap when considering specifically long-lived older adults from Amazonas, a state in Brazil.

Octogenarians are those aged 80 years or older and may also receive the following denominations: older adults, very old adults, advanced older adults, and long-lived older adults ${ }^{(17)}$.

The present study may bring contributions to science, especially to geriatric nursing, thus promoting the undertaking of further studies on the theme, whose results may contribute to care actions provided for this population.

This study originated after daily care observations, which led to the need for researching the functional capacity of older adults, specifically long-lived ones, due to specificities presented during their care, thus aiming at future interventions for this population, with the purpose of promoting aging with quality of life.

\section{OBJECTIVE}

To assess the functional capacity of long-lived older adults from Amazonas registered in a primary health care unit of the Brazilian Unified Health System in Belém, a city in the state of Pará.

\section{METHOD}

\section{Ethical aspects}

The present study met the ethical aspects of resolution 466/12 of the Brazilian National Health Council, and was approved by the research ethics committee of the University of the State of Pará.

\section{Study design, setting, and period}

This was a cross-sectional study with an observational and analytical approach. It was carried out in a primary health care unit of the district of Guamá in Belém, Pará. The district chosen has one of the greatest populations of people aged 80 years or older. The present study was carried out in 2015.

\section{Study population and inclusion and exclusion criteria}

From a reference population of older adults $(\mathrm{N}=187)$, the initial sample $(\mathrm{N}=127)$ was obtained after sample calculation. The final sample was made up of long-lived older adults $(\mathrm{N}=116)$, with a loss of 11 (8.6\%) participants due to their refusal in participating in the study. The inclusion criteria adopted for the sample in this study were being older adults aged 80 years or older from both genders, registered in the primary health care unit of the city.

\section{Study protocol}

For data collection, a structured form including the variables of interest for the study was prepared, such as sociodemographic and economic characteristics (age, gender, origin, marital status, years of study, monthly income, job, cohabitation, and number of children).

The Mini-Mental State Examination (MEEM) was used for cognitive function screening. The following cut-off scores were suggested for this study: illiterate $=19 ; 1-3$ years of education $=23$; $4-7$ years of education $=24 ;>7$ years of education $=28^{(18)}$. Funcional capacity was assessed using the Functional Independence Measure (FIM), which was translated and adapted to Brazil in $2000^{(19)}$. It originated in the 1980s and was developed in the United States for assessment of individuals undergoing rehabilitation ${ }^{(20)}$.

The FIM assesses functional performance (functional independence) of an older person based on the undertaking of a set of 18 tasks (motor and cognitive skills), which refer to subscales or dimensions denominated as self-care, sphincter control, transfers, locomotion, communication, and social cognition. This allows objectively quantifying the older person's need for assistance or independence, thus contributing to the planning of specific treatments. In the tasks assessed by the FIM, each item may be classified in a 7-level dependence scale, in which 1 corresponds to total dependence and 7 to complete independence, that is, normality in the undertaking of tasks in an independent way. Therefore, the TOTAL FIM score (motor and cognitive part) may range from 18 (completely dependent) to 126 (completely independent $)^{(17)}$.

Only the motor FIM was assessed in the present study, by means of the self-care, sphincter control, transfers, and locomotion 
dimensions. This instrument is part of the functional capacity assessment measures' list recommended by the Brazilian Ministry of Health, and is included in the Aging and Health of the Elderly booklet ${ }^{(18)}$, whose use is recommended in primary health care. Still regarding the FIM, it is worth mentioning that the motor function evaluation dimension receives a score that may range from 13 to 91 points $^{(21-22)}$.

\section{Analysis of the results and statistics}

A database organized in the SPSS (Statistical Package for the Social Sciences) software for Windows 20.0 was created for data analysis. For treatment of socioeconomic and demographic data (quantitative variables), descriptive analyses were carried out with position and dispersion measures, and the Pearson's chi-square test was applied for nominal, categorical, or ordinal variables.

\section{RESULTS}

According to the data shown in Table 1, the greatest proportion of long-lived older adults were women, in comparison with men of the sample analyzed. The prevalent age group was 80-89 years, and most of the older adults were widowed, had children, lived with their families, came from the countryside of the state of Pará, had a monthly income of up to one minimum wage, did not have a paid job, and presented a low education level.

It is worth mentioning that, in this study, the application of the Mini-Mental State Examination (MMSE) associated with education level in years of study was carried out. It was observed that $72.2 \%$ of the illiterate long-lived older adults presented a cognitive evaluation score below 19 points, showing that the lower the education level, the lower the score in the MMSE.

Table 2 presents the performance of older adults according to the motor FIM dimensions. The four motor FIM dimensions correspond to self-care (eating, grooming, bathing, dressing - upper, dressing - lower, and toileting), sphincter control (bladder and bowel), mobility (bed, chair or wheelchair, toilet, tub or shower), and locomotion (walking or wheelchair, and stairs).

According to the participants' reports, most of them already presented modified independence for self-care activities, as well as sphincter control for $40 \%$, and locomotion for $54.3 \%$. Regarding mobility, most of the older adults required supervision.

According to the reports of the participants in the study regarding the relationship between FIM and gender, no difference was found in self-care and sphincter control performance ( $p$-value $\geq 0.05$ ). However, for sphincter control, the proportion of men with complete independence was greater compared to women, who already presented modified independence. Regarding mobility (transfers), men presented complete independence, whereas women required supervision, with $\mathrm{p}$-value $\leq 0.05$. However, in locomotion, a greater proportion of men presented modified independence compared to women, with $p$-value $\leq 0.05$.

Table 3 shows that functional independence for self-care and sphincter control activities were presented by more independent older adults, mostly in the 80-89 age group, with a $p$-value $(\leq 0.05)$. Regarding performance for transfers and locomotion, approximately $60 \%$ of the older adults in the $80-89$ age group still maintained modified independence; however, more than $75 \%$ of the older adults in more advanced age groups already required some type of assistance, according to the dimensions evaluated.

Table 1 - Sociodemographic profile of the long-lived older adults who participated in the study, Belém, Pará, Brazil, 2015 ( $N=116)$

\begin{tabular}{|c|c|c|}
\hline Variables & $f$ & $\%$ \\
\hline \multicolumn{3}{|l|}{ Gender } \\
\hline Female & 75 & 64.7 \\
\hline Male & 41 & 35.3 \\
\hline \multicolumn{3}{|l|}{ Age $($ mean $=85.1 ; S D=4.703 \pm)$} \\
\hline $80-89$ & 100 & 86.2 \\
\hline $90-99$ & 14 & 12.1 \\
\hline 100 or + & 2 & 1.7 \\
\hline \multicolumn{3}{|l|}{ Marital status } \\
\hline Widowed & 56 & 48.3 \\
\hline Married or living with a partner & 41 & 35.3 \\
\hline Divorced & 6 & 5.2 \\
\hline Single & 13 & 11.2 \\
\hline \multicolumn{3}{|l|}{ Children } \\
\hline Yes & 113 & 97.4 \\
\hline No & 3 & 2.6 \\
\hline \multicolumn{3}{|l|}{ Living arrangement } \\
\hline With the family & 104 & 89.7 \\
\hline Alone & 9 & 7.8 \\
\hline Other & 3 & 2.6 \\
\hline \multicolumn{3}{|l|}{ Origin } \\
\hline Countryside & 76 & 65.6 \\
\hline Belém & 32 & 27.6 \\
\hline Another state & 7 & 6.0 \\
\hline Another country & 1 & 0.9 \\
\hline \multicolumn{3}{|l|}{ Monthly income (MW) } \\
\hline Up to one MW & 107 & 92.2 \\
\hline Two MW & 8 & 6.9 \\
\hline$>$ Three to four MW & 1 & 0.9 \\
\hline \multicolumn{3}{|l|}{ Paid job } \\
\hline No & 107 & 92.2 \\
\hline Yes & 9 & 7.8 \\
\hline \multicolumn{3}{|l|}{ Education level } \\
\hline Illiterate/None & 42 & 36.2 \\
\hline$<$ One year of study & 14 & 12.1 \\
\hline One to three years of study & 39 & 33.6 \\
\hline Four to eight years of study & 17 & 14.7 \\
\hline More than eight years of study & 4 & 3.4 \\
\hline
\end{tabular}

Note: Measures in frequency and proportion.

Table 2 - Distribution of the long-lived older adults' performance according to the motor Functional Independence Measure dimensions, Belém, Pará, Brazil, $2015(\mathrm{~N}=116)$

\begin{tabular}{lccccccccc}
\hline $\begin{array}{l}\text { Dimensions of } \\
\text { the motor FIM }\end{array}$ & \multicolumn{8}{c}{ Functional independence levels } \\
& $\mathbf{7}$ & $\mathbf{6}$ & $\mathbf{5}$ & $\mathbf{4}$ & $\mathbf{3}$ & $\mathbf{2}$ & $\mathbf{1}$ & \\
& 1.7 & 86.2 & 0.0 & 6.9 & 0.9 & 2.6 & 1.7 & 100 \\
& 38.8 & 44.8 & 0.0 & 6.0 & 5.2 & 0.9 & 4.3 & 100 \\
Self-care & 25.0 & 19.8 & 38.8 & 7.8 & 3.4 & 0.0 & 5.2 & 100 \\
Sphincter control & 9.5 & 54.3 & 3.4 & 9.5 & 10.3 & 6.9 & 6.0 & 100 \\
Mobility (Transfers) & Locomotion & & & & & &
\end{tabular}

Note: I (Complete Independence=7); MI (Modified Independence=6); S (Supervision=5); MiA (Minimal Assistance $=4)$; MoD (Moderate Assistance $=3$ ); MaA (Maximal Assistance=2); TA (Total Assistance=1); FIM = Functional Independence Measure. 
Table 3 - Distribution of the level of independence of the long-lived older adults who participated in the study according to age group, Belém, Pará, Brazil, 2015 ( $N=116)$

\begin{tabular}{|c|c|c|c|c|c|c|}
\hline \multirow{3}{*}{ Dimension } & \multirow{3}{*}{ Variables } & \multicolumn{4}{|c|}{ Age group } & \multirow{3}{*}{$P^{*}$} \\
\hline & & \multicolumn{2}{|c|}{$80-89$} & \multicolumn{2}{|c|}{$90+$} & \\
\hline & & $\mathbf{n}$ & $\%$ & $\mathbf{n}$ & $\%$ & \\
\hline \multirow[t]{7}{*}{ Self-care } & Total assistance & 0 & 0.0 & 2 & 12.5 & \multirow{7}{*}{$<0.000$} \\
\hline & Maximal assistance & 1 & 1.0 & 2 & 12.5 & \\
\hline & Moderate assistance & 1 & 1.0 & 0 & 0.0 & \\
\hline & Minimal assistance & 4 & 4.0 & 4 & 25.0 & \\
\hline & Supervision & 0 & 0.0 & 0 & 0.0 & \\
\hline & Modified independence & 92 & 92.0 & 8 & 50.0 & \\
\hline & Complete independence & 2 & 2.0 & 0 & 0.0 & \\
\hline \multirow[t]{7}{*}{ Sphincter control } & Total assistance & 1 & 1.0 & 4 & 25.0 & \multirow{7}{*}{$<0.000$} \\
\hline & Maximal assistance & 1 & 1.0 & 0 & 0.0 & \\
\hline & Moderate assistance & 6 & 6.0 & 0 & 0.0 & \\
\hline & Minimal assistance & 3 & 3.0 & 4 & 25.0 & \\
\hline & Supervision & & 0.0 & & 0.0 & \\
\hline & Modified independence & 47 & 47.0 & 5 & 31.3 & \\
\hline & Complete independence & 42 & 42.0 & 3 & 18.8 & \\
\hline \multirow[t]{7}{*}{ Mobility } & Total assistance & 2 & 2.0 & 4 & 25.0 & \multirow{7}{*}{$<0.000$} \\
\hline & Maximal assistance & & 0.0 & & 0.0 & \\
\hline & Moderate assistance & 1 & 1.0 & 3 & 18.8 & \\
\hline & Minimal assistance & 7 & 7.0 & 2 & 12.5 & \\
\hline & Supervision & 41 & 41.0 & 4 & 25.0 & \\
\hline & Modified independence & 21 & 21.0 & 2 & 12.5 & \\
\hline & Complete independence & 28 & 28.0 & 1 & 6.3 & \\
\hline \multirow[t]{7}{*}{ Locomotion } & Total assistance & 3 & 3.0 & 4 & 25.0 & \multirow{7}{*}{0.001} \\
\hline & Maximal assistance & 6 & 6.0 & 2 & 12.5 & \\
\hline & Moderate assistance & 8 & 8.0 & 4 & 25.0 & \\
\hline & Minimal assistance & 8 & 8.0 & 3 & 18.8 & \\
\hline & Supervision & 4 & 4.0 & 0 & 0.0 & \\
\hline & Modified independence & 59 & 59.0 & 3 & 18.8 & \\
\hline & Complete independence & 12 & 12.0 & 0 & 0.0 & \\
\hline
\end{tabular}

Note: Measures in frequency and proportion; Pearson's chi-square test $(p){ }^{*} P$-value $(\leq 0.05)$.

\section{DISCUSSION}

Feminization is a well-known phenomenon in old age. Longevity is greater among women when compared to men ${ }^{(9,23-24)}$. Studies carried out with long-lived older adults emphasize the prevalence of women ${ }^{(1,17,25-34)}$.

Widowhood is the most prevalent marital status, especially among women. The feminization process is associated with the widowhood process. With an increase in life expectancy, the proportion of widows has followed this process, with a reduction in the number of married widows. Some factors are associated with this fact, such as greater longevity among women and the cultural prevalence of men remarrying younger women ${ }^{(35-36)}$.

More than half of the elderly in the study reported coming from the countryside of the state. Older adults from countryside regions may present a better functional capacity, which may be due to healthier life habits ${ }^{(17)}$.

Most participants in the study had a monthly income of one minimum wage, mainly coming from retirement. Older people with restricted financial income have limited access to nutritional and social care, emphasizing health and education, which are significant influencing factors for quality of life. Socioeconomic factors affect the health of older adults ${ }^{(26,37)}$.

Illiteracy was the education level with the highest percentage among the participants in the study. The historical context of the 20th century, which is associated with the period of birth and childhood of the long-lived older adults, presented an access limitation to the public school network. Those who lived in the countryside area experienced this difficulty due to the lack of available schools, the difficulty of locomotion due to geographic space, and other reasons ${ }^{(38)}$. Low education levels are prevalent among the elderly ${ }^{(9,23)}$ and also stands out among long-lived older adults ${ }^{(29,39)}$.

Low education levels and illiteracy are factors directly associated with the impairment of older adults' understanding level, thus contributing to a limitation in access to information ${ }^{(40)}$. The present study showed that, the lower the education level, the lower the performance in cognitive assessment, which was corroborated by other studies ${ }^{(25,41)}$.

Low cognitive performance may interfere with long-lived older adults' survival, and routine cognitive assessment of the elderly is a necessary practice, because cognitive impairment may impact the functional performance of long-lived older adults ${ }^{(34)}$.

Identification of functional performance is an important health indicator for older adults from all age groups. This is influenced by multifactorial conditions and associated with the interaction of demographic, social, economic, epidemiological, and behavioral factors. It is worth mentioning that the aging process is natural and associated with a gradual decrease in functional capacity ${ }^{(5)}$.

Evaluation of mobility directs visibility for assessment of functional decline, which is considered essential for studying the relationship between functional capacity and sociodemographic characteristics, chronic conditions ${ }^{(42)}$, and health-related events, because these situations may directly interfere with activities of daily living ${ }^{(22)}$.

A study carried out in Criciúma, a city in the state of Santa Catarina, to research the functional capacity of 20 institutionalized long-lived older adults using the FIM observed that they presented modified independence in the self-care (33\%), sphincter control (50\%), and locomotion (27.2\%) dimensions, whereas in mobility/transfers (25\%), they presented modified dependence of the supervision type ${ }^{(20)}$, which was similar to the results found in the present study.

Women presented worse functional performance than men. The feminization phenomenon may explain this fact, which is a process previously evidenced demographically, and, although presenting greater life expectancy, this group consequently presents greater functional loss. Some hypotheses may explain this, such as higher prevalence of non-lethal disabling conditions among them (osteoporosis and depression, for example) and the fact that women present a higher number of health conditions, when compared to men in the same age group ${ }^{(43)}$. One study carried out in Brazil that evaluated frailty in 511 non-institutionalized older adults showed that women were more frail ${ }^{(9)}$.

Similarly, loneliness maximized by widowhood may affect functional impairment with a tendency for widowed people to take less care of their health ${ }^{(43)}$. Studies carried out with long-lived older adults showed a prevalence of greater functional loss in women $^{(1,13,27,29,32,44)}$. 
In the relationship between the motor FIM and age group, octogenarians presented modified independence in the selfcare, sphincter control, and locomotion dimensions, whereas nonagenarians and centenarians ranged between modified independence and dependence, which showed that, the higher the age group, the worse the functional capacity, and that this condition may be expected in the population due to functional losses associated with physiological aging.

Functional impairment increases with age. The greatest proportion of older adults with some type of dependence belongs to the 80 years or older age group ${ }^{(1)}$. Some studies associate a decline in functional capacity with aging process $s^{(30,43-46)}$.

The human aging process influences some determinants, such as reduction in physical fitness, resulting in a gradual decrease in daily living activities, which will affect older adults' quality of life. Older adults, when reaching 80 years healthily and maintaining themselves functionally active, may characterize younger functional age when compared to inactive 60 years old adults ${ }^{(38)}$.

Detecting older adults' level of dependence by observing several constituents of physical fitness is of utmost importance for direction and selection of individual or group interventions, with the aim of improving or maintaining functional capacity, especially those associated with activities of daily living, which should be encouraged ${ }^{(47)}$.

Because the aging process is heterogeneous, there are longlived older adults at advanced ages with a good functional performance. Older adults, in at least some countries, are more independent than those from previous generations. This situation suggests a slightly more optimistic future for long-lived older adults and challenges the idea that increase in longevity and life expectancy of successive generations of older adults must be always dealt with concern ${ }^{(1)}$.

Functional capacity is directly associated with older adults' potential to independently decide and act in their activities of daily living. Assessments on functional capacity allow learning the profile of older adults, which will contribute to the establishment of practices to delay or prevent disabilities ${ }^{(38)}$.

One cohort study carried out in Denmark with nonagenarians born in 1905 and 1915 suggests that long-lived older adults may live up to more advanced ages with a good overall functioning ${ }^{(25)}$.

Individuals with good education levels are less likely to be exposed to health-related risk factors and submitted to poor work conditions. A high education level contributes to the access to information, health-related changes in life style, especially with regard to its promotion and following of guidelines for better quality of life ${ }^{(45)}$. This positively affects functional capacity.

\section{Study limitations}

This cross-sectional study presented limitations, such as data obtained from a specific period of time and sample size, not allowing generalizations for this population; however, it allowed the promotion of reflections on future practices.

\section{Contributions to the nursing, healthcare, or public policy areas}

The present study presented as contributions the promotion of a discussion on the functional capacity of long-lived older adults, specifically those from Amazonas, since this is a pioneering study on the theme in this region and may support further studies, thus allowing a particular approach and care for the older adults of the region.

\section{CONCLUSION}

The worldwide and Brazilian aging process leads to the emergence of several challenges to provide comprehensive care for the elderly. Therefore, identifying health conditions of the long-lived older adults, which is an age group that stands out in old age, is of utmost importance for interventions directed to meet the demands of this population and promote a better confrontation of physical-functional losses in this age group.

The results of the present study also showed the prevalence of modified independence, in spite of the advanced age of the elderly in the sample, which suggests that reflection on the adoption of health promotion and disability prevention measures in the future may be a strategy for improving quality of life, as well as reducing costs for the Brazilian Unified Health System, older adults, and families who are directly involved by dependence.

\section{FUNDING}

Amazonia Foundation for Studies and Research Support FAPESPA - Edict 006/2013.

\section{REFERENCES}

1. Jagger C, Collerton JC, Davies K, Kingston A, Robinson LA, Eccles MP, et al. Capability and dependency in the Newcastle 85+ cohort study: projects of future care needs. BMC Geriatr. 2011;11:21. doi: https://doi.org/10.1186/1471-2318-11-21

2. Menezes TMO, Lopes RLM. Significado do cuidado no idoso de 80 anos ou mais. Rev Eletr Enf 2012;14(2):240-7. doi: http://dx.doi. org/10.5216/ree.v14i2.13176

3. Taekema DG, Gussekloo J, Westendorp RG, Craen AJ, Maier AB. Predicting survival in oldest old people. Am J Med. 2012;125(12):1188-94.e1. doi: https://doi.org/10.1016/j.amjmed.2012.01.034

4. Betiolli SE, Lenardt MH, Willig MH, Michel T. Cultural practices of health care in the perspective of elder elderly people. Cienc Cuid Saude. 2014;13(2):318-26. doi: http://dx.doi.org/10.4025/cienccuidsaude.v13i2.21739

5. Costa NP, Polaro SHI, Vahl EAC, Gonçalves LHT. Storytelling: a care technology in continuing education for active ageing. Rev Bras Enferm [Internet]. 2016; 69(6): 1068-75. doi: http://dx.doi.org/10.1590/0034-7167-2016-0390 
6. Comini CC, Melo JVM, Ferreira FR, Lima-Costa MF. Capacidade funcional de idosos: análise das questões de mobilidade, atividades básicas e instrumentais da vida diária via Teoria de Resposta ao Item. Cad Saúde Pública. 2015;31(5):931-945. doi: http://dx.doi. org/10.1590/0102-311X00093214

7. Santos MIPO, Griep RH. Capacidade funcional de idosos atendidos em um programa do SUS em Belém (PA). Ciênc Saúde Colet. 2013;18(3):753-761. doi: http://dx.doi.org/10.1590/S1413-81232013000300021

8. Borges GF, Benedetti TRB, Farias SF. Atividade física habitual e capacidade funcional percebida de idosas do sul do Brasil. Pensar Prat. 2011;14(1):1-11. doi: https://doi.org/10.5216/rpp.v14i1.12314

9. Carneiro JA, Ramos GCF, Barbosa ATF, Mendonça JMG, Costa FM, Caldeira AP. Prevalence and factors associated with frailty in noninstitutionalized older adults. Rev Bras Enferm. 2016;69(3):408-415. doi: http://dx.doi.org/10.1590/0034-7167.2016690304i

10. Brito TA, Fernandes MH, Coqueiro RS, Jesus CS. Falls and functional capacity in the oldest old dwelling in the community. Texto Contexto Enferm. 2013; 22(1):43-51. doi: http://dx.doi.org/10.1590/S0104-07072013000100006

11. Santos VR, Christofaro DGD, Gomes IC, Codogno JS, Santos LL, Freitas IFF. Association between bone mass and functional capacity among elderly people aged 80 years and over. Rev Bras Ortop. 2013;48(6):512-518. doi: http://dx.doi.org/10.1016/j.rboe.2013.12.012

12. Hoefelmann CP, Benedetti TRB, Antes DL, Lopes MA, Mazo GZ, Korn S. Aptidão funcional de mulheres idosas ativas com 80 anos ou mais. Motriz: J Phys Ed [Internet]. 2011 [cited 2016 Feb 01];17(1):19-25. Available from: http://www.scielo.br/pdf/motriz/v17n1/a03v17n1.pdf

13. Santos SB, Oliveira LB, Menegotto IH, Bós AJG, Soldera CLC. Dificuldades auditivas percebidas por moradores longevos e não longevos de uma instituição de longa permanência para idosos. Estud Interdiscipl Envelhec[Internet]. 2012 [cited 2015 Mar 01];17(1):125-43. Available from: https://seer.ufrgs.br/RevEnvelhecer/article/view/18172/23192

14. Lourenço TM, Lenardt MH, Kletemberg DF, Seima MD, Tallmann AEC, Neu DKM. Capacidade funcional no idoso longevo: uma revisão integrativa. Rev Gaúcha Enferm. 2012;33(2):176-185. doi: http://dx.doi.org/10.1590/S1983-14472012000200025

15. Guimarães IN, Moraes F, Segundo JP, Silva I, Andrade TG, Moraes CR. Risk factors for mortality in octogenarians undergoing myocardial revascularization surgery. Arq Bras Cardiol. 2011;96(2):94-8. doi: http://dx.doi.org/10.1590/S0066-782X2011005000008

16. Veras R. Population aging today: demands, challenges and innovations. Rev Saúde Públ. 2009;43(3):548-54. doi: http://dx.doi.org/10.1590/ S0034-89102009005000025

17. Lenardt $\mathrm{MH}$, Carneiro NHK. Associação entre as características sociodemográficas e a capacidade funcional de idosos longevos da comunidade. Cogitare Enferm. 2013;18(1):13-20. doi: http://dx.doi.org/10.5380/ce.v18i1.31299

18. Ministério da Saúde. (BR). Secretaria de Atenção à Saúde. Departamento de Atenção Básica. Envelhecimento e Saúde da Pessoa Idosa. Brasília; 2006 (Cadernos de Atenção Básica, 19).

19. Riberto M, Miyazaki MH, Jorge Filho D, Sakamoto H, Battistella LR. Reprodutibilidade da versão brasileira da Medida de Independência Funcional. Acta Fisiátr. 2001;8(1):45-52. doi: https://dx.doi.org/10.5935/0104-7795.20010002

20. Hoepers NJ, Oliveira ACC, Schwalm MT, Soratto MT, Ceretta LB. Medidas de independência funcional em uma instituição de longa permanência de idosos. Estud Interdiscipl Envelhec[Internet]. 2013 [cited 2015 Mar 02];18(1):7-26. Available from: https://seer.ufrgs.br/ RevEnvelhecer/article/view/19998/26988

21. Santos VR, Gomes IC, Santos LL, Agostinete RR, Freitas Jr IF. Associação entre fatores de risco cardiovascular e capacidade funcional de idosos longevos. Medicina (Ribeirão Preto). 2013;46(1):10-6. doi: http://dx.doi.org/10.11606/issn.2176-7262.v46i1p10-16

22. Rocha AKAA, Silva Jr ED, Novaes MM, Franco CIF. Análise da independência funcional em pacientes com neuropatia hanseniana assistidos pelo centro de referência em hanseníase da cidade de Campina Grande - Paraíba. SaBios: Rev Saúde Biol [Internet]. 2014 [cited 2016 Jan 02];9(3):8-16. Available from: http://revista2.grupointegrado.br/revista/index.php/sabios2/article/view/1133/625

23. Santos MIPO, Portella MR. Conditions of functional health literacy of an elderly diabetics group. Rev Bras Enferm [Internet]. 2016;69(1):156164. doi: http://dx.doi.org/10.1590/0034-7167.2016690121i

24. Pereira FM, Besse M. Fatores associados à independência funcional de idosos residentes em instituição de longa permanência. Acta Fisiátr[Internet]. 2011 [cited 2015 Oct 14];18(2):66-70. Available from: http://www.revistas.usp.br/actafisiatrica/article/view/103599/102062

25. Christensen K, Thinggaard M, Oksuzyan A, Steenstrup T, Andersen-Ranberg K, Jeune B, et al. Physical and cognitive functioning of people older than 90 years: a comparison of two Danish cohorts born 10 years apart. Lancet. 2013;382(9903):1507-13. doi: https://doi.org/10.1016/ S0140-6736(13)60777-1

26. Inouye K, Pedrazzani ES. Instruction, social economic status and evaluation of some dimensions of octogenarians' quality of life. Rev LatinoAm Enfermagem. 2007;15(spe):742-7. doi: http://dx.doi.org/10.1590/S0104-11692007000700005

27. Terry DF, Sebastiani P, Andersen SL, Perls TT. Disentangling the roles of disability and morbidity in survival to exceptional old age. Arch Intern Med. 2008;168(3):277-83. doi: https://doi.org/10.1001/archinternmed.2007.75

28. Landi F, Russo A, Liperoti R, Danese P, Maiorana E, Pahor M, et al. Daily pain and functional decline among old-old adults living in the community: results from the ilSIRENTE study. J Pain Symptom Manage. 2009; 38(3):350-357. doi: https://doi.org/10.1016/ jjpainsymman.2008.10.005

29. De Rango F, Montesanto A, Berardelli M, Mazzei B, Mari V, Lattanzio F, et al. To grow old in southern Italy: a comprehensive description of the old and oldest old in Calabria. Gerontology. 2011;57(4):327-34. doi: https://doi.org/10.1159/000316941 
30. Nogueira SL, Ribeiro RCL, Rosado LEFPL, Franceschini SCC, Ribeiro AQ, Pereira ET. Determinant factors of functional status among the oldest old. Rev Bras Fisioter. 2010;14(4):322-329. doi: http://dx.doi.org/10.1590/S1413-35552010005000019

31. Aires M, Paskulin LMG, Morais EP. Functional Capacity of Elder Elderly: Comparative Study in Three Regions of Rio Grande do Sul. Rev LatinoAm Enfermagem. 2010;18(1):11-7. doi: http://dx.doi.org/10.1590/S0104-11692010000100003

32. Rabuñal-Rey R, Monte-Secades R, Gomez-Gigirey A, Pértega-Díaz S, Testa-Fernández A, Pita-Fernández S, et al. Electrocardiographic abnormalities in centenarians: impact on survival. BMC Geriatr. 2012; 12(15). doi: https://doi.org/10.1186/1471-2318-12-15

33. Ansai JH, Sera CTN. Percepção da autonomia de idosos longevos e sua relação com fatores sociodemográficos e funcionais. Rev Kairós [Internet]. 2013 [cited 2015 mar. 10]; 16(3):189-200. Available from: http://revistas.pucsp.br/kairos/article/view/18643/13831

34. Mossakowska M, Broczek K, Wieczorowska-Tobis K, Klich-Rączka A, Jonas M, Pawlik-Pachucka E, et al. Cognitive Performance and Functional Status Are the Major Factors Predicting Survival of Centenarians in Poland. J Gerontol A Biol Sci Med Sci. 2014; 69(10):1269-1275. doi: https://doi.org/10.1093/gerona/glu003

35. Camarano AA. Envelhecimento da população brasileira: uma contribuição demográfica. Rio de Janeiro: Instituto de Pesquisa Econômica Aplicada (IPEA); 2002. Available from: http://www.ipea.gov.br/portal/images/stories/PDFs/TDs/td_0858.pdf

36. Both TL, Alves AR, Pereira C, Teixeira TP. Uma abordagem para o luto na viuvez da mulher idosa. RBCEH. 2012; 9(1):67-78. doi: https://doi. org/10.5335/rbceh.2012.2788

37. Morais EP, Rodrigues RAP, Gerhardt TE. Os idosos mais velhos no meio rural: realidade de vida e saúde de uma população do interior gaúcho. Texto Contexto Enferm. 2008; 17(2):374-383. doi: http://dx.doi.org/10.1590/S0104-07072008000200021

38. Biolchi C, Portella M, Vargas AC, Silveira MM, Colussi EL. A capacidade funcional de um grupo de idosos centenários. Rev Kairós [Internet]. 2013 [cited 2016 Jan 20]; 16(2):213-226. Available from: http://revistas.pucsp.br/index.php/kairos/article/view/18545/13732

39. Lopes GL, Santos MIPO. Funcionalidade de idosos cadastrados em uma unidade da Estratégia Saúde da Família segundo categorias da Classificação Internacional de Funcionalidade. Rev. Bras. Geriatr. Gerontol. 2015; 18(1):71-83. doi: http://dx.doi. org/10.1590/1809-9823.2015.14013

40. Farias RG, Santos SMA. Influência dos determinantes do envelhecimento ativo entre idosos mais idosos. Texto Contexto Enferm. 2012; 21(1):167-176. doi: http://dx.doi.org/10.1590/S0104-07072012000100019

41. Alvarenga MRM, Oliveira MAC, Faccenda O, Souza RA. Perfil social e funcional de idosos assistidos pela estratégia da saúde da família. Cogitare Enferm. 2011; 16(3):478-85. doi: http://dx.doi.org/10.5380/ce.v16i3.20944

42. Mo L, Ding D, Pu S-Y, Liu Q-H, Li H, Dong B-R, et al. Patients Aged 80 Years or Older are Encountered More Potentially Inappropriate Medication Use. Chin Med J (Engl). 2016; 129(1):22-7. doi: http://doi.org/10.4103/0366-6999.172558

43. Nunes MCR, Ribeiro RCL, Rosado LEFPL, Franceschini SC. The influence of sociodemographic and epidemiological characteristics on the functional capacity of elderly residents in the city of Ubá, Minas Gerais. Rev Bras Fisioter. 2009; 13(5):376-382. doi: http://dx.doi.org/10.1590/ S1413-35552009005000055

44. Alves LC, Leite IC, Machado CJ. Factors associated with functional disability of elderly in Brazil: a multilevel analysis. Rev Saúde Públ. 2010; 44(3):468-478. doi: http://dx.doi.org/10.1590/S0034-89102010005000009

45. Scattolin FAA, Colombo RCR, Diogo MJD. Predictors of functional Independence in elderly patients with heart failure. Acta Fisiátr [Internet]. 2007 [cited 2016 Feb 15]; 2007; 14(4):219-225. Available from: http://www.revistas.usp.br/actafisiatrica/article/view/102866/101156

46. Engberg H, Christensen K, Andersen-Ranberg K, Vaupel JW, Jeune B. Improving Activities of Daily Living in Danish Centenarians-But Only in Women: A Comparative Study of Two Birth Cohorts Born in 1895 and 1905. J Gerontol A Biol Sci Med Sci [Internet]. 2008 [cited 2015 Feb 15]; 63(11):1186-1192. Available from: https://www.ncbi.nlm.nih.gov/pmc/articles/PMC2751852/pdf/nihms104010.pdf

47. Gonçalves LHT, Silva AH, Mazo GZ, Benedetti TRB, Santos SMA, Marques S. O idoso institucionalizado: avaliação da capacidade funcional e aptidão física. Cad Saúde Pública. 2010; 26(9):1738-1746. doi: http://dx.doi.org/10.1590/S0102-311X2010000900007 